\title{
NEW SPECIES, RECORDS, AND SYNONYMS OF CHILEAN THERIDIID SPIDERS (ARANEAE, THERIDIIDAE)*
}

\author{
By Walter C. Sedgwick \\ Bar M Ranch, Boston, Ga. 31626
}

This paper is a supplement to Levi (1967), without which it would not have been possible. Since the northern provinces of Chile are so arid, most previous collecting has been done in the southern part. My collecting was mostly in the provinces of Santiago and Valparaiso, as well as those few enclaves and rivers in the northern desert which support vegetation. As my trip to Chile occurred during the dry Chilean summer, I concentrated on collecting under stones and using a head-light at night. This yielded an abundance of specimens of Theridion. One Dipoena and two species of Theridion are new, another is a new record for Chile. There is one new synonym of a Chilean theridiid and two new synonyms as a result of examining type specimens of Nicolet's Araneidae which had been placed in the wrong family.

The new Dipoena cartagena is unusual because its mouth parts are specialized (Fig. I4), apparently for holding onto legs of ants, Dipoena's prey. I do not know of other instances of similar adaptation of mouth parts; but they may have been overlooked in the minute specimens. Mouth parts of spiders are conservative and hardly differ in different genera.

I am very grateful to Dr. Willard Whitcomb for allowing me to accompany him on his trip, Dr. and Mrs. Luciano Campos for their hospitality, Drs. Cortez and Charlin for their patience and kindness during the trip, and Luis Cartagena and Luis Alvarez for their collecting enthusiasm. I am especially and most sincerely grateful to Dr. Herbert Levi of Harvard for the drawings and the continuing advice and help he has given me throughout the preparation of this paper and for examining the Nicolet types. Dr. M. Hubert of the Museum National d'Histoire Naturelle, Paris, found the Nicolet types and made them available to me for study.

Achaearanea tepidariorum (C. L. Koch) (Levi, 1955: 32, figs. 69-70, 83-84; 1963b: 21 5, map I ; i967: 5, 7-8.) Additional record. Coquimbo Province: Pampilla, I4. II. 73, one + (L. Alvarez).

Achaearanea acoreense (Berland) (Achaearanea geochares Levi, 1955: 20, figs. 39-40, 46. Achaearanea teja Levi, 1967: 8, figs. 8-10.

*Manuscript received by the editor December 5, 1973. 
New SYnonymy.) Additional record. Valparaiso Province: La Cruz, 20. I. 73, three $\sigma^{x}$, five o.

Steatoda grossa (C. L. Koch) (Levi, I962: 26; 1967: 7.) Additional record. Tarapaca Province: Agricultural Experiment Station, Azapa, 27. I. 73, under the outer layer of a banana tree, two $ᄋ$, six immatures.

Steatoda sabulosa (Tullgren) (Levi, I962: 30, figs. 25-27; 1967: 7.) Additional record. Coquimbo Province: Portilla, 20. I. 73, $2600 \mathrm{~m}$ elev. under a rock, one 9 .

Theridion amarga Levi (Theridion foliaceum, - Levi, I963c: 536, figs. 44-46. Theridion amarga Levi, 1967: 7-8.) Additional record. Valparaiso Province: $\mathrm{La}$ Cruz, 20. I. 73, two $\sigma^{7}$, three 9 .

Theridion volubile Keyserling (Levi, I963c: 527, figs. IO-I3.) Previously known from Venezuela to Peru. Additional record. Tarapaca Province: Agricultural Experiment Station, Azapa, under the outer layer of a banana tree, two $\$$; and Taltape, Camarones Valley in Cartaderid sp. (Foxtail), 29. I. 73, one $0^{\top}$.

\section{Theridion whitcombi n.sp.}

Figures I-4

Holotype. Female from Agricultural Experiment Station, Azapa, Tarapaca Province, Chile 27. I. I973 (W. Sedgwick) in the Museum of Comparative Zoology. It is named after Dr. Whitcomb for the encouragement he has given me over many years. It was found under the outer layer of a banana tree.

Description. Carapace yellow white, with a triangular dark band beginning one-third of the distance from the posterior median eyes to the cervical groove and which narrows from the anterior to form a blunt point at the cervical groove. It is indented anteriorly (Fig. I). There is a black band around the carapace ending at the first coxa, continuing in the form of a very thin line with a black spot the width of the anterior median eyes in the center of the clypeus. The eye region is light. The legs have black spots, and the distal half of the tarsi are a very light brown. The size of the two specimens is different. The abdomen has two white spots slightly less than their diameter apart between the genital groove and spinnerets, with a pair of smaller white spots anterior to the spinnerets (Fig. 4). The dorsal abdominal pattern is similar to Theridion elli having a wavy white band which narrows posteriorly. It is bordered on both sides with a dark brown band (Fig. I). Total length $\mathrm{I} .84 \mathrm{~mm}$. Carapace $0.69 \mathrm{~mm}$ long, $0.59 \mathrm{~mm}$ wide. First femur, $1.22 \mathrm{~mm}$; patella and 

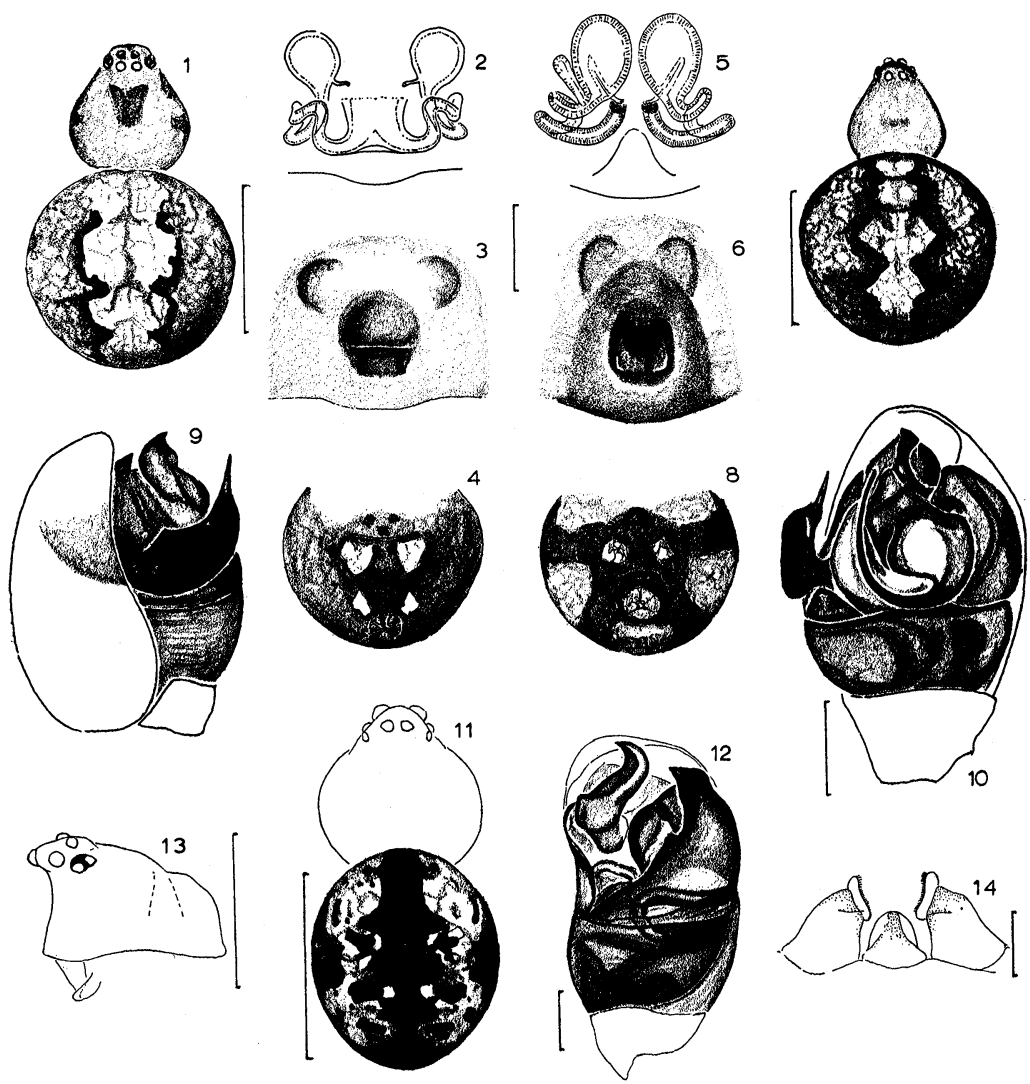

Figs. 1-4. Theridion whitcombi n. sp. 1. Carapace and abdomen of female. 2. Dorsal view of epigynum. 3. Epigynum. 4. Venter of abdomen. Figs. 5-10. Theridion elli n. sp. 5. Dorsal view of epigynum. 6. Epigynum. 7. Female. 8. Venter of abdomen. 9, 10. Left palpus. 9. Mesal. 10. Ventral.

Figs. 11-14. Dipoena cartagena n. sp. 11. Carapace and abdomen of male. 12. Left palpus, ventral view. 13. Carapace, chelicera, endite. 14. Endites and labium.

Scale lines, $0.1 \mathrm{~mm}$; except $1,7,11,13,1.0 \mathrm{~mm}$. 
tibia, I.25 mm; metatarsus, 0.9I $\mathrm{mm}$; tarsus, $0.47 \mathrm{~mm}$. Second patella and tibia, $0.75 \mathrm{~mm}$; third, $0.53 \mathrm{~mm}$; fourth, $0.84 \mathrm{~mm}$.

Diagnosis. This species differs from Theridion volubile by the shape of the internal genitalia, the ducts of which loop less than those of Theridion volubile (Fig. 2).

Record. One female paratype collected with holotype deposited in the Museum of Comparative Zoology.

\section{Theridion elli n.sp.}

Figures 5-10

Holotype. Female from Antumapu, Santiago Province, Chile I8. I. 1973 (L. Alvarez) in the Museum of Comparative Zoology. The specific name is a noun in apposition, after a friend who has encouraged me greatly in arachnology.

Description. Carapace light brown, with a wide margin around the sides, turning into a thin black line at the clypeus. The eye region is dark (Fig. 7). The legs are generally spotted in mid and distal portions, the distal half of the tarsi being a light brown. The abdomen is variable in size and shape, but always has a white spot at each end of the genital groove and two smaller spots located between the genital groove and the spinnerets (Fig. 8). The dorsal pattern of the abdomen consists of seven white spots stretching from near the pedicel to near the spinnerets. The first two are small, the third larger, and the subsequent spots become smaller towards the spinnerets. The spots are bordered in black which is sometimes a continuous border, sometimes in spots (Fig. 7). The male is similar. Both male and female were found under rocks and papers. Total length of female $2.13 \mathrm{~mm}$. Carapace $0.88 \mathrm{~mm}$ long, $0.75 \mathrm{~mm}$ wide. First femur, $1.25 \mathrm{~mm}$; patella and tibia, I.4I mm; metatarsus, 1.00 $\mathrm{mm}$; tarsus, $0.53 \mathrm{~mm}$. Second patella and tibia, $0.88 \mathrm{~mm}$; third, $0.59 \mathrm{~mm}$; fourth, $0.91 \mathrm{~mm}$. Total length of male $1.47 \mathrm{~mm}$. Carapace $0.69 \mathrm{~mm}$ long, $0.63 \mathrm{~mm}$ wide. First femur, I.3 I mm; patella and tibia, $\mathrm{I} .34 \mathrm{~mm}$; metatarsus, $\mathrm{I} .06 \mathrm{~mm}$; tarsus, $0.56 \mathrm{~mm}$. Second patella and tibia, $0.84 \mathrm{~mm}$; third, $0.59 \mathrm{~mm}$; fourth, $0.84 \mathrm{~mm}$.

The female type has a short, blind extra duct originating from the left seminal receptacle (Fig. 5).

Diagnosis. This species can be differentiated from Theridion volubile and Theridion whitcombi by the epigynum (Fig. 6) in which the ducts are not visible (as in Theridion volubile) and which differs in shape from that of Theridion whitcombi. The ducts open in black spots of the depression (Figs. 5, 6). 
Records. Santiago Prov.: Santiago, Dept. of Agriculture Building at University of Chile, three $\sigma^{*}$, $q$ paratypes (W. Sedgwick). Antumapu two $q$ paratypes (L. Alvarez). ( $9, \sigma^{\infty}$ paratypes placed in American Museum of Natural History, New York.)

\section{Dipoena cartagena n.sp.}

Figures II-I 4

Holotype. Male from Bosques al Sur de Quintero, Valparaiso Province, Chile, 20. II. I973 (Luis Cartagena) in the Museum of Comparative Zoology. It was found under a leaf. It is named for the collector. The specific name is a noun in apposition.

Description. Carapace, sternum, legs olive-brown. Tarsi of legs light colored. Dorsum of abdomen with a black pattern and white pigment spots in areas without black (Fig. II). Sides and venter black. Venter with a pair of white spots side by side. Posterior median eyes 0.6 diameters of anterior medians. Laterals the radius of anterior medians. Anterior median eyes slightly more than their diameter apart, almost touching laterals. Posterior median eyes slightly less than one diameter apart, about their diameter from laterals. The labium and endites are modified, the endites with a distal brush and the labium with a transparent lobe on each side (Fig. 14). Total length $2.0 \mathrm{~mm}$. Carapace $0.98 \mathrm{~mm}$ long, $0.90 \mathrm{~mm}$ wide, $0.76 \mathrm{~mm}$ high. First femur, $1.52 \mathrm{~mm}$. Second patella and tibia, I.00 $\mathrm{mm}$; third, $0.69 \mathrm{~mm}$; fourth, $1.18 \mathrm{~mm}$.

Dipoena species feed on ants. This specimen is unusual because unlike others of the genus, the endites seem to be specially adapted probably for holding the legs of the ant while the spider pierces it with its fangs.

Diagnosis. This species is close to Dipoena pumicata (Keyserling) but differs from this and related species by the twisted embolus and plain projecting conductor of the palpus (Fig. 12).

Phoroncidia pennata (Nicolet), new combination.

Gasteracantha pennata Nicolet, 1849, in Gay, Historia Fisica y Politica de Chile, 10(3): 474, pl. 5, fig. 5. Female type in poor condition from Chile. No. 5524 in the Muséum National d'Histoire Naturelle, Paris, examined July 1973.

Ulesanis pennata, - Simon, 1894, Histoire Naturelle des Araignées 1: 556.

Glyptogona pennata, - Simon, 1895, Histoire Naturelle des Araignées 1: 867. Roewer, 1942, Katalog der Araneae, 1: 891.

Phoroncidia coquimbo Levi, 1964, Bull. Mus. Comp. Zool., 131: 77, figs. 38-41, + , $\hat{o}$. Female holotype from Hacienda Illapel, Prov. Coquimbo, Chile, in the Institut Royal des Sciences Naturelles de Belgique, Brussels. NEW SYNONYMY. 
Nicolet's type is in very poor condition and has the lateral projections of the abdomen relatively longer than in previous specimens.

Phoroncidia variabilis (Nicolet), new combination

Gasteracantha variabilis Nicolet 1849 in Gay, Historia Fisica y Politica de Chile, 10(3): 476. Female holotype from Chile, no. 5523 in the Muséum National d'Histoire Naturelle, Paris, examined, July 1973.

Glyptogona pennata,-Simon, 1895, Histoire Naturelle des Araignées 1: 1: 867. Roewer, 1942, Katalog der Araneae, 1: 891.

Phoroncidia margamarga Levi, 1964, American spiders of the genus Phoroncidia (Araneae: Theridiidae). Bull. Mus. Comp. Zool. 131: 77, figs. 30-34, + . Female holotype from Marga Marga, Prov. Valparaiso, Chile, in the Institut Royal des Sciences Naturelles de Belgique, Brussels. Levi, 1967, Bull. Mus. Comp. Zool. 136: 18, figs. 16-18, ô. NEW sYNonYMY.

\section{References Cited}

LEVI, H. W.

1955. The spider genera Coressa and Achaearanea in America north of Mexico (Araneae: Theridiidae). Am. Mus. Novit., no. 1718: 1-33.

1962. The spider genera Steatoda and Enoplognatha in America (Araneae, Theridiidae). Psyche, 69:11-36.

1963a. American spiders of the genus Achaearanea and the new genus Echinotheridion (Araneae, Theridiidae). Bull. Mus. Comp. Zool., 129 : 187-240.

1963b. American spiders of the genus Theridion (Araneae: Theridjidae). Bull. Mus. Comp. Zool., 129: 481-589.

1967. The theridiid spider fauna of Chile, Bull. Mus. Comp. Zool., 136: 1-20. 

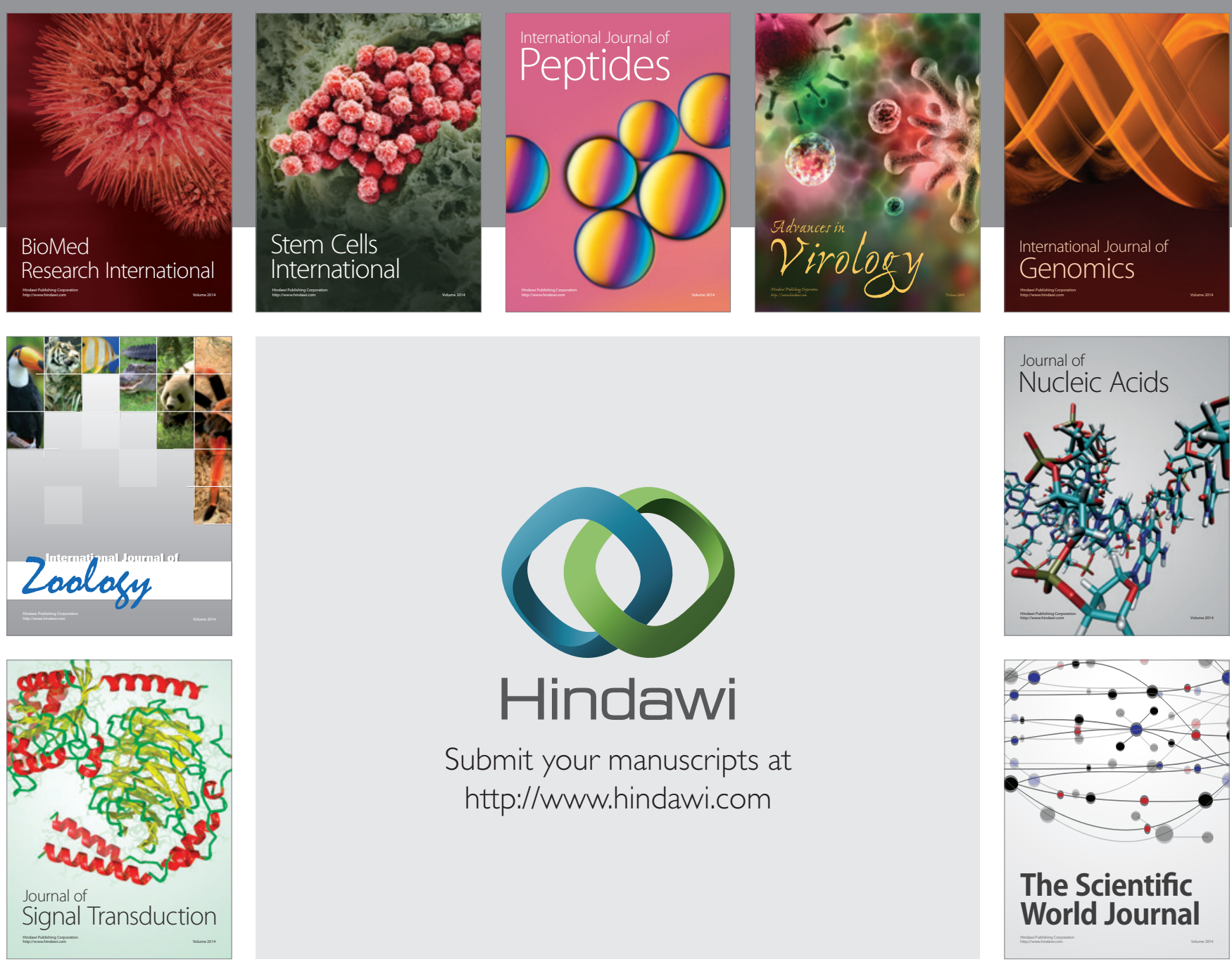

Submit your manuscripts at

http://www.hindawi.com
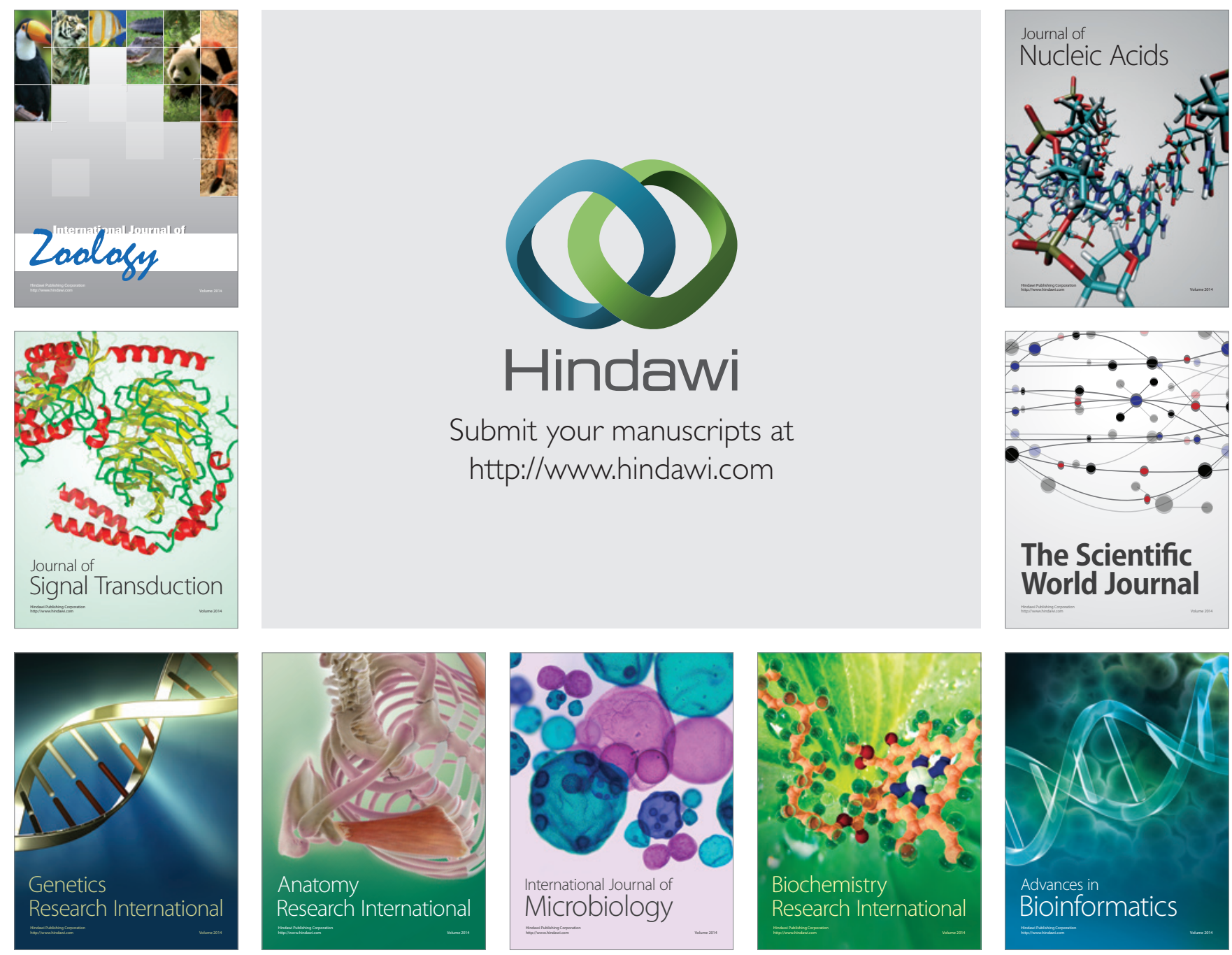

The Scientific World Journal
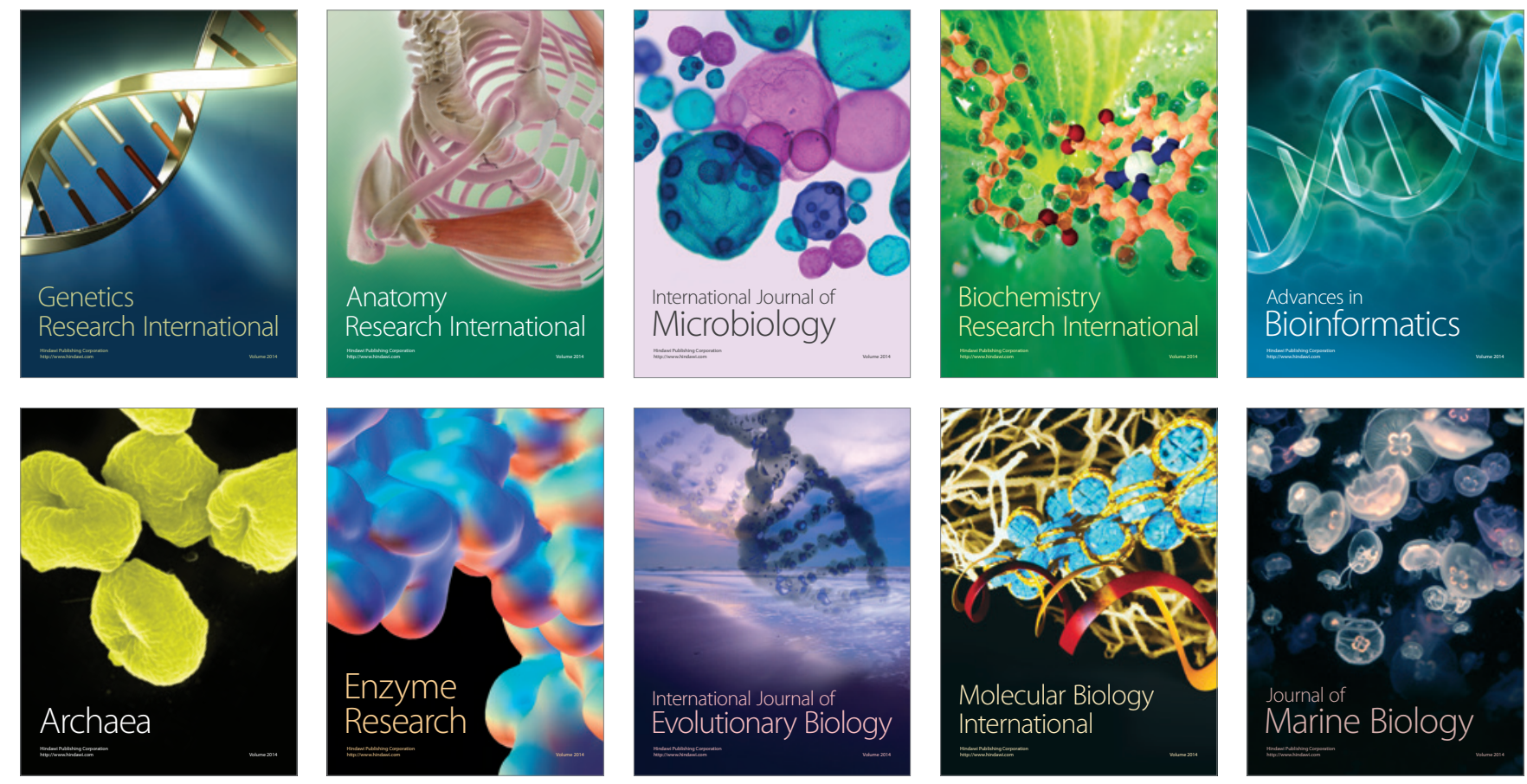